Original Article

\title{
Molecular transduction in receptor-ligand systems by planar electromagnetic fields
}

\author{
Transdução molecular em sistemas receptor-ligante por campos electromagnéticos planares
}

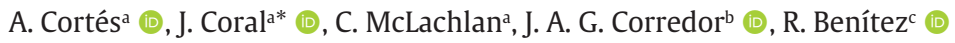 \\ aDepartment of Molecular Physics, Synthetic Vaccine and New Drug Research Institute - IVSI, Popayán, Colombia. \\ ${ }^{\text {b} C h e m i s t r y ~ D e p a r t m e n t, ~ U n i v e r s i d a d ~ d e l ~ C a u c a, ~ P o p a y a ́ n, ~ C o l o m b i a . ~}$ \\ 'Chemistry Department, Chemical of Natural Products group, Universidad del Cauca, Popayán, Colombia.
}

\begin{abstract}
The coupling of a ligand with a molecular receptor induces a signal that travels through the receptor, reaching the internal domain and triggering a response cascade. In previous work on T-cell receptors and their coupling with foreign antigens, we observed the presence of planar molecular patterns able to generate electromagnetic fields within the proteins. These planes showed a coherent (synchronized) behavior, replicating immediately in the intracellular domain that which occurred in the extracellular domain as the ligand was coupled. In the present study, we examined this molecular transduction - the capacity of the coupling signal to penetrate deep inside the receptor molecule and induce a response. We verified the presence of synchronized behavior in diverse receptorligand systems. To appreciate this diversity, we present four biochemically different systems - TCR-peptide, calcium pump-ADP, haemoglobin-oxygen, and gp120-CD4 viral coupling. The confirmation of synchronized molecular transduction in each of these systems suggests that the proposed mechanism would occur in all biochemical receptor-ligand systems.
\end{abstract}

Keywords: cell signaling, molecular coupling, molecular patterns, quantum coherence, structure-function relationship.

\begin{abstract}
Resumo
A ligação de um ligante com um receptor molecular induz um sinal que viaja através do receptor, chegando ao domínio interno e disparando uma cascata de resposta. Em trabalhos anteriores em receptores de células T e sua ligação com antígenos estranhos, observamos a presença de padrões moleculares planares capazes de gerar campos eletromagnéticos dentro das proteínas. Esses planos mostraram um comportamento coerente (sincronizado), replicando, instantaneamente, no domínio intracelular o que ocorreu no domínio extracelular, enquanto o ligante era acoplado. No presente estudo, examinamos essa transdução - a capacidade de um sinal de acoplamento de penetrar profundamente a molécula receptora e induzir uma resposta. Verificamos a presença de um comportamento coerente em sistemas diversos de receptor-ligante. Para apreciar essa diversidade, apresentamos quatro sistemas bioquímicos diferentes: TCR-peptídeo, ADP-bomba de cálcio, hemoglobina-oxigênio e gp120-CD4 acoplamento viral. A confirmação de transdução molecular sincronizada em cada um desses sistemas sugere que o mecanismo proposto ocorreria em todos os sistemas bioquímicos receptor-ligante.
\end{abstract}

Palavras-chave: sinalização celular, acoplamento molecular, padrões moleculares, coerência quântica, relação estrutura-função.

\section{Introduction}

When a ligand couples with a receptor in a biochemical system, a signal is understood to travel through the receptor, inducing a conformational change that triggers a response cascade (Wu, 2013). Two types of receptor exist. The first, found anchored to cell membranes, features three domains (intracellular, transmembrane and extracellular). The second type, of which an example would be the carrier molecule haemoglobin, is not anchored, enjoying freedom of movement and possessing only a single domain (Hall, 2015). In anchored receptors, coupling of the ligand with the external domain induces a conformational change throughout the interior of the receptor. An identical action occurs in non-anchored receptors. These conformational changes have not been clearly explained.

We analyzed more than twenty receptor-ligand systems known to feature conformational changes. We selected four

*e-mail: jecs53@gmail.com

Received: December 24, 2019 - Accepted: September 26, 2020

This is an Open Access article distributed under the terms of the Creative Commons Attribution License, which permits unrestricted use, distribution, and reproduction in any medium, provided the original work is properly cited. 
systems with widely differing biochemical functions: T cell receptor (TCR) with peptide, cell membrane calcium pumpADP (SERCA), the haemoglobin-oxygen carrier system, and the gp120-CD4 viral coupling. In the latter three systems, the calcium pump, haemoglobin, and gp120 molecules are considered to act as receptors. The transduction processes in these systems are understood as follows (in each case, the required transmission of the signal cannot be fully explained using only mechanical criteria (Bischof and Del Giudice, 2013)):

Calcium pump-ADP. Ion pumps located in cell membranes use ATP as an energy source to move calcium ions out of the cell against a concentration gradient. The mechanism put forward to explain this proposes conformational changes in the different domains of the protein. When the ATP molecule couples to the calcium pump, the pump closes, trapping ions in the transmembrane domain. Subsequently, the ATP is hydrolyzed to ADP, which becomes dissociated, thereby inducing an opening in the extracellular domain of the pump and allowing the trapped calcium ions to be released on the other side of the membrane, i.e. against the electrochemical gradient (Toyoshima et al., 2007; Toyoshima et al., 2004).

Haemoglobin-oxygen. Haemoglobin is some 2,000 times heavier than the molecules of oxygen it is designed to transport (Torsoni et al., 2002). Coupling nevertheless is able to induce a conformational change in the entire protein. The coupling of the first oxygen molecule to one of the four available sites allows an identical, consequential coupling of a second, third and fourth oxygen molecule. The spatial forms adopted by the haemoglobin to hold on to the four molecules are highly stable. It is this that enables it to carry the oxygen successfully all the way from the lungs to the muscles (Biswal and Vijayan, 2002).

Gp120-CD4. The HIV virus also makes potent use of a conformational change within its gp120 protein. This change, on the coupling of two opposite charges, aspartate 368 in gp120 and arginine 59 in CD4, causes the V1/V2 arm or loop to spring open, leaving exposed the domain responsible for the determinant fusion with the CCR5 co-receptor (Liu et al., 2008; Huang et al., 2007).

The mechanisms of molecular transduction that induce activation of the T-cell receptor (TCR), another receptor-ligand system, are not clearly understood (Adams et al., 2011). Different approaches have been taken in the past to account for molecular transduction. A number of authors refer to cell receptors as "mechanosensors" that convert the mechanical energy of ligand-receptor coupling into biochemical signals, inducing transduction of the signal (Kim et al., 2009; Kim et al., 2012). (An example is induced adjustment, a hypothetical mechanism by which receptors scan the ligand searching for complementarity. This structural reordering may be transmitted along the entire length of the receptor, inducing a conformational change to trigger the signaling (Bridgeman et al., 2012)).

In earlier work, we observed that planar molecular patterns were present in Major Complex Histocompatibility Class II (MHC-II) molecules. The patterns, known as Planar Electromagnetic fields of Cortés-Coral (or PECC), enabled us to present a coherent explanation of the process of MHC-II coupling with foreign peptides (Cortés et al., 2017b;
Cortés et al., 2017a). PECC are also found in other proteins. Most significantly, they are present in all of the receptor molecules studied in the present article, in which we propose an evidence-based, molecular mechanism for transduction and subsequent activation, especially in TCR.

PECC are formed by fully conserved residues of a single chemical species (e.g. Gly) arranged on the same plane within the protein, extending across the macromolecule. The result is the organized presence, in the internal protein structure, of specific PECC-Gly planes, PECC-Pro planes, PECC-Leu planes, and so on (Cortés et al., 2013; Cortes and Coral, 2015; Cortés et al., 2017b). Importantly, from crystal structure analysis of the planes, using Molecular Viewer software, and studying the behavior of the fully conserved residues it is possible to infer that all the component residues are mutually interlinked by a single electromagnetic field, which shows the same planar geometric form in all of the molecules studied. This field is generated by an aromatic residue (i.e. Tyr, Phe, Trp) that is always found at the point of origin of all of the PECC (see the Figures in this article).

As a precondition for generating any electromagnetic field, the movement of electrical charge is required (Anselmo et al., 2008; Anselmo et al., 2009). Aromatic residues possess electrons in movement, able to instigate such a field. This field may therefore be generated by movement of electrons in the aromatic residue present in all PECC and always located so as to be in electromagnetic communication with all residues of the plane. The effect of the field is to cause these component residues to behave in a synchronized manner. As a result, an action applied at one point (amino acid) of the PECC is replicated at all the other points of the PECC. The coupling signal is thereby replicated deep in the interior of the receptor (Cortés et al., 2017a). The existence of PECC in biomolecules would explain two experimental findings. The first is the detection of electromagnetic fields generated by proteins, identified by Ćosić et al., 2006 (Ćosić et al., 2006), from the Royal Melbourne Institute of Technology; the second finding is that of highly ordered electromagnetic fields generated by DNA molecules, in a study directed by Nobel laureate Luc Montagnier (Montagnier et al., 2011).

We studied these PECC planes in various protein crystal structures. On comparing the proteins in their free (uncoupled) and coupled states, it was noted that some charged residues exhibited intramolecular ionic pairing. We therefore focused our attention only on the PECC formed by these residues. These were given the name PECC-ionic (PECC-i) and constitute planes that span the entire protein.

In the case of the TCR molecule, the PECC-i extends from the TCR intracellular domain to its most exposed point, known as the Complementary Determining Region (CDR), located in the $\alpha \beta$ domains and responsible for recognizing the peptide presented by the Human Leukocyte Antigen (HLA) molecule in humans (Bridgeman et al., 2012).

The coordinated ionic pairing seen in all of the PECC-i demonstrates characteristics typical of quantum coherence. If all the component residues of the PECC are interconnected by a same field of a possible electromagnetic nature, it would cause the ionic pairing to occur in a coordinated 
way in the whole structure. Quantum phenomena have two main characteristics: quantization of energy and quantum engagement. Quantization of energy does not allow the existence of intermediate energy values, so that in the PECC system there could only be two quantized states - the free and the coupled - excluding intermediate energy values, while quantum engagement may be present here, interconnecting the PECC residues. These are properties that recent findings have shown may be present in biological phenomena. Two common examples of this include the process of photosynthesis in plants and the ability in birds to navigate using Earth's magnetic field (Ball, 2011; Lambert et al., 2013). In the first, photons are captured from the environment and channeled to the photosynthesis reaction center, so efficiently that almost every photon is transferred (the success rate is nearly $100 \%$ ). Various researchers have indicated that photon-electron interactions in this process may well be coherent, with their waves extending to more than one molecule while staying in step and reinforcing one another. Similarly, in the case of birds, photons of light striking the retina of the eye appear to create pairs of free radicals that can be reoriented by magnetic fields, enabling these electron pairs to exist in a state of quantum coherence (Lambert et al., 2013). Importantly then, quantum laws may apply not only under strict laboratory conditions, but in everyday biological situations.

\section{Material and Methods}

We studied a number of structures of receptor-ligand systems with widely differing biochemical functionality. In this article, we describe some of these (TCR-peptide, calcium pump-ADP, haemoglobin-oxygen and gp120-CD4). Each crystal structure is presented in its free state and in its coupled state. A search for crystal structures was performed in the Structure database of the National Center for Biotechnology Information (NCBI), using the search criteria "TCR coupled form" and "TCR free" for TCR molecules; this same search strategy was carried out with the other systems - calcium pump-ADP, haemoglobin-oxygen and gp120-CD4 - via the Global Query Cross-Database Search System, ENTREZ. Once the MMDB ID was obtained from the Structure database, it was possible to locate the PDB ID of each selected crystal structure (see Table 1 and Figures 1-3). The crystal structures selected were then located, using the PDB ID, in the PDB database (http:// www.rcsb.org/pdb/home/home.do). The results of the searches yielded the following three-dimensional protein crystal structures: for TCR $(\alpha \beta)$ coupled with peptides (1FYT (Hennecke et al., 2000)) as well as free TCR $(\alpha \beta)$ structures (4GKZ (Holland et al., 2012), 1KGC (Kjer-Nielsen et al., 2002), 3QEU (Borbulevych et al., 2011), 2HAC ( $\zeta \zeta$ transmembrane dimer domain) (Call et al., 2006)); for the other systems: calcium pump-ADP (free: 2ZBE (Toyoshima et al., 2007), coupled: 2ZBD (Toyoshima et al., 2004)), haemoglobinoxygen (free: 1JY7 (Biswal and Vijayan, 2002), coupled: 3B75), and gp120-CD4 (free: 3DNN (Liu et al., 2008), coupled: 2QAD (Huang et al., 2007)).

From a large database, we analyzed protein sequences of every receptor available in the Conserved Domains Database (CDD), also from NCBI. We then selected protein sequences of only that species most abundant in the CDD for each structure, so that for the TCR $(\alpha \beta)$ and haemoglobin molecules, all sequences related to Homo sapiens were selected; for the calcium pump, those of Oryctolagus cuniculus, and for gp120, only the HIV type I species. Sequences were aligned in Clustal Omega (a multiple sequence alignment algorithm available in the database of the European Molecular Biology Laboratory-European Bioinformatics Institute (EMBL-EBI, 2018).

The fully conserved residues with electrical charge were then selected, as were the aromatic residues. In the molecules coupled with the ligand, we looked for intramolecular ionic pairings of opposite charges. We then further located the same residues in the molecules in their free state. All of these residues were selected and placed in the virtual displays for 3D analysis, to locate them spatially.

The methodology used to visualize the crystal structures was designed by the authors from prior studies on complexes. It uses bioinformatics tools including Cn3D

Table 1. Fully conserved charged and aromatic residues that form PECC planes, in the receptor-ligand systems studied.

\begin{tabular}{|c|c|c|c|c|c|c|c|}
\hline Receptor & & & & & & Hb & \\
\hline \multirow{2}{*}{ PDB ID } & \multirow{2}{*}{ 1KGC } & \multirow{2}{*}{ 3QEU } & \multirow{2}{*}{ 4GKZ } & \multirow{2}{*}{ 1FYT } & $2 Z B B E$ & $1 \mathrm{JY7}$ & 3DNN \\
\hline & & & & & 2ZBD & $3 B 75$ & 2QAD \\
\hline \multirow{7}{*}{$\begin{array}{l}\text { Charged } \\
\text { residues }\end{array}$} & D135 & D128 & D133 & D135 & R560 & E43 & D368 \\
\hline & K136 & K129 & K134 & K136 & R671 & R92 & K487 \\
\hline & K184 & K177 & K182 & K184 & K297 & K127 & K490 \\
\hline & D 186 & D179 & D184 & D 186 & E696 & D6 & E492 \\
\hline & -- & -- & -- & -- & E90 & -- & -- \\
\hline & -- & -- & -- & -- & R110 & -- & -- \\
\hline & -- & -- & -- & -- & E113 & -- & -- \\
\hline $\begin{array}{l}\text { Aromatic } \\
\text { residues }\end{array}$ & Y159 & Y152 & Y157 & Y159 & F57 & H58 & F93 \\
\hline
\end{tabular}

(TCR, T-cell receptor; Ca pump, Calcium pump; Hb, Haemoglobin; gp120) 

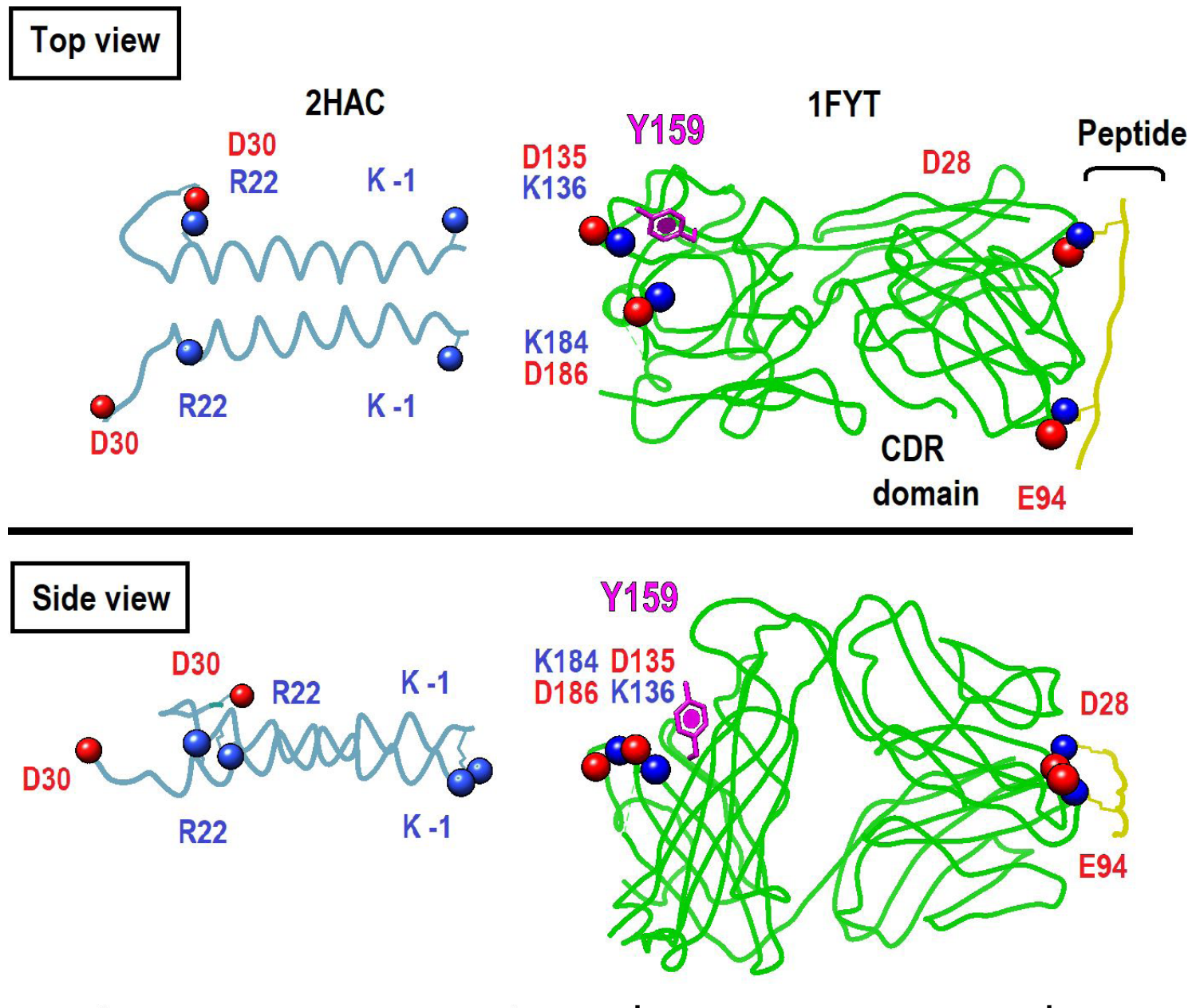

$\zeta \zeta$ transmembrane dimer

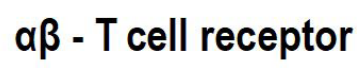

Figure 1. Spatial positions of fully conserved, charged residues and peptide-recognition residues in TCR. These together form a PECC-i by which the signal reaches the $\zeta \zeta$ transmembrane dimer domain. Image recordings taken from Jmol.

(macromolecular structure display, version 4.3, 2011; Cn3D, 2011) and Jmol (an open-source Java viewer for chemical structures in three dimensions, version 12.0 , 2011; Jmol, 2011). Using the tools of the visualizers, we selected only the fully conserved, charged residues and placed them in the 3D structures of the free and coupled states. We compared residue by residue in all states, looking for possible intramolecular pairings between opposite charges in the coupled 3D structures. The residues that formed new pairs were registered and recorded in images taken from Jmol.

\section{Results}

Table 1 shows the fully conserved charged and aromatic residues in the receptor of the systems studied in this paper. These residues form PECC planes and occupy equivalent spatial positions in the receptors in both the free and coupled state.

Figure 1 shows the spatial positions of the fully conserved, charged residues of the TCR $(\alpha \beta)$. These residues form planes that extend throughout the entire complex, from the $\zeta \zeta$ transmembrane dimer domain (D30, R22) to the peptiderecognition residues (D28, E94) in the CDR ( $\alpha \beta$ chains). The positive residues of the coupled peptide (shown in blue) form two ionic pairings with the peptide-recognition residues exposed by the TCR. The side view shows the planarity in the complex; this plane constitutes the PECC-i.

Figure 2 shows four TCR $(\alpha \beta)$ molecules (1KGC, 3QEU, 4GKZ, 1FYT). In Figure 2a), b) and c), the molecule is shown in its free (uncoupled) form, whereas in Figure $2 d$ ) the TCR is in its peptide-coupled form. The charged residues are shown in red for negative charges and blue for positive charges. The fully conserved residues are highlighted in the boxes beneath each figure. 
a) 1KGC
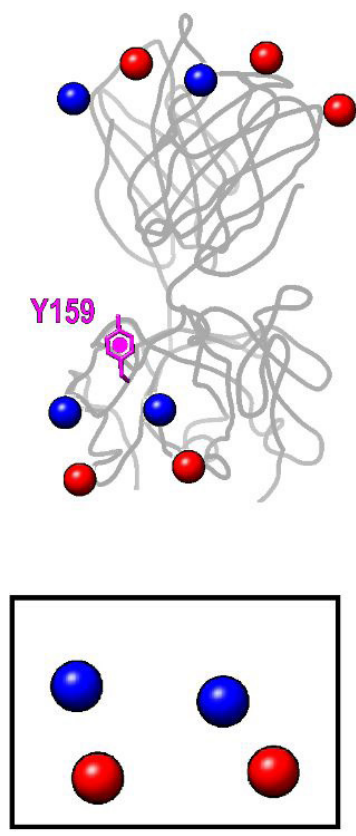

K184 D186
K136 D135
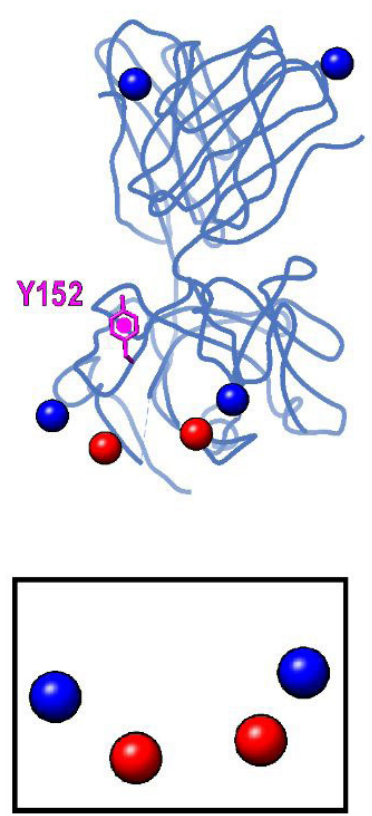

K177 K129

D179 D128 c) $4 \mathrm{GKZ}$
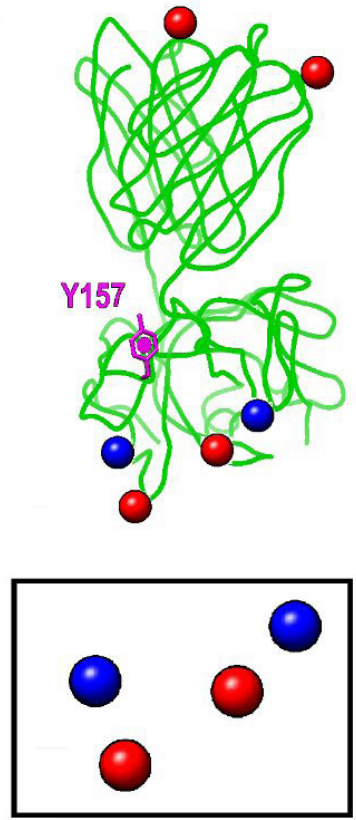

K182 K134

D184 D133

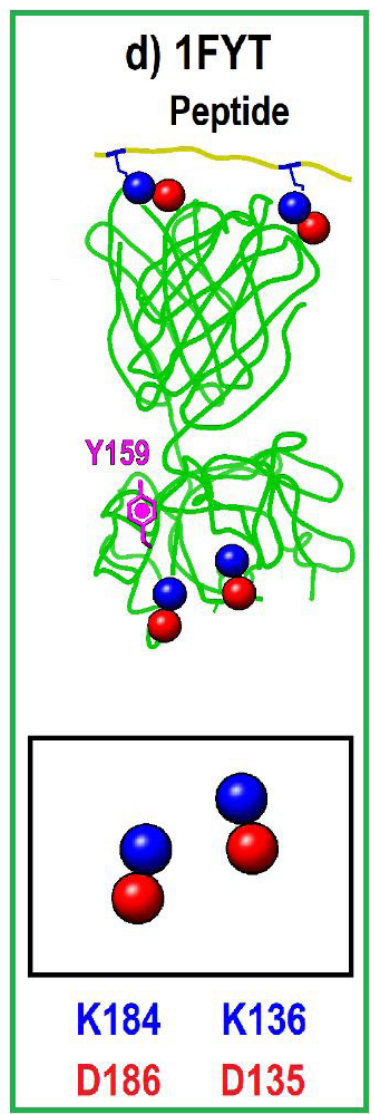

Figure 2. $\operatorname{TCR}(\alpha \beta)$ molecules in free (a, b, c) and coupled (d) states, showing the charged residues in red for negative charges and blue for positive charges. The fully conserved residues are highlighted in the boxes below each figure. Image records taken from Jmol.

Figure 3 shows the PECC-i of some of the receptorligand systems studied by the authors: calcium pump-ADP (a,b,c) haemoglobin-oxygen (d,e,f) and gp120-CD4 (g,h,i). All systems are shown with the free (uncoupled) form on the left. The central and right-hand representations show the coupled form.

\section{Discussion}

The only pairs of residues that produce a strong and stable coupling in a receptor-ligand system are electrically charged residues. These are always located in the most exposed part of the proteins, due to their hydrophilic nature (Wang et al., 1993). They also interact best with electromagnetic fields (Pokutnyi and Naumenko, 2014). From this it follows that the amino acids with the best properties for bringing about the transduction of an electromagnetic signal in a receptor are those, such as the aspartate (D), glutamate (E), arginine (R), histidine (H), and lysine $(\mathrm{K})$ residues, that have an electric charge (Table 1 ).

Certain mutations effected on the TCR, for example, have shown that by replacing charged amino acids with other oppositely-charged ones, it is possible to induce activation of T cells (Lynch et al., 2013; Fukui et al., 2000). Also, the mutation of electrical amino acids by other residues with no charge is linked to the induction of a number of diseases. In sickle cell anaemia, the E6 amino acid of the beta chain of the haemoglobin is substituted for the hydrophobic V6 residue (Ingram, 2004), while in HIV infection, blocking of the charged D2 and D11 residues of the CCR5 molecule of T-lymphocytes impedes coupling of the virus (Cormier et al., 2000). Charged amino acids are thus clearly important in the functionality of proteins.

The PECC-i planes function precisely by means of their charged amino acids. These residues acquire a coordinated, synchronized behaviour due to an interconnection produced by the electromagnetic field. This would explain the functional importance of this class of amino acids in proteins. To corroborate this, we looked at each residue of the PECC-i in different crystal structures of proteins of several receptor-ligand systems with diverse biological functions. Free and coupled systems were compared.

In all the studied structures, it was found that the charged residues formed ionic pairings with residues of opposite charges. This is because all the residues mentioned are interconnected by the same electromagnetic field. This type of ionic pairing could not be produced by mechanical conformational changes for two reasons: 1 ) because too much energy would be required at the time of molecular ligand-receptor coupling and 2) if the conformational changes occurred mechanically, they could operate with 
Top view, uncoupled

a) $2 Z B E$

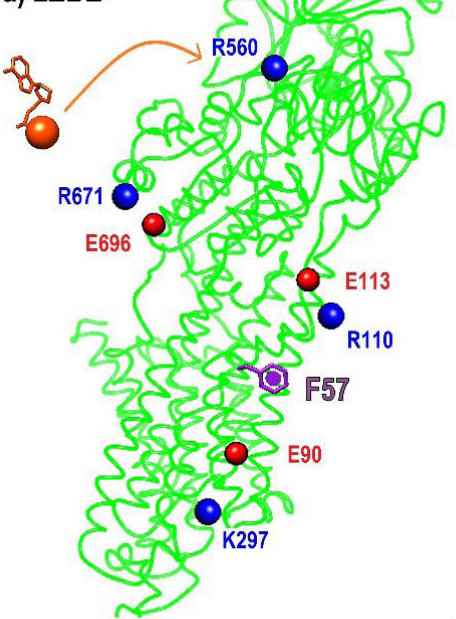

b) 2ZBD

Top view, coupled

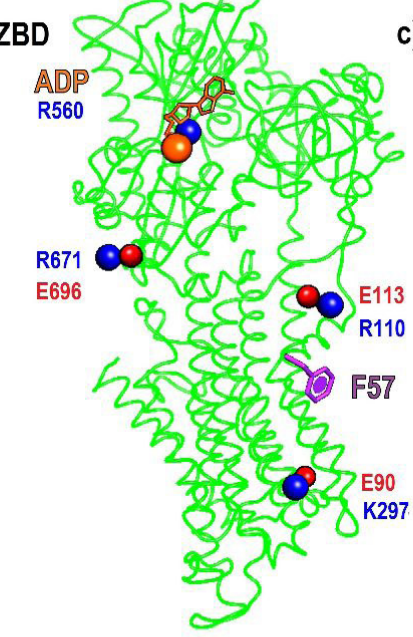

Side view, coupled

C) 2ZBD

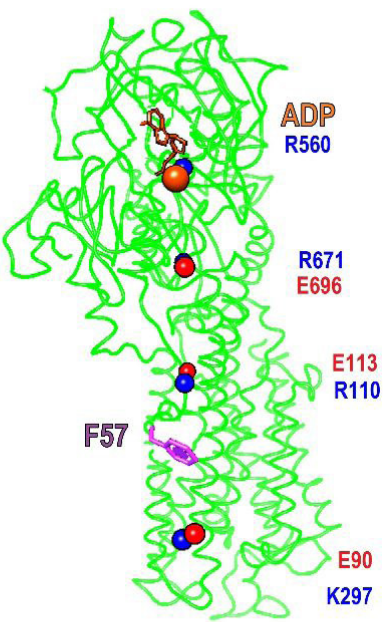

d) $1 \mathrm{JY} 7$

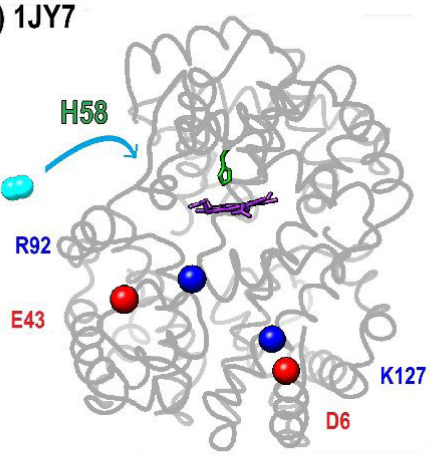

e) $3 B 75$

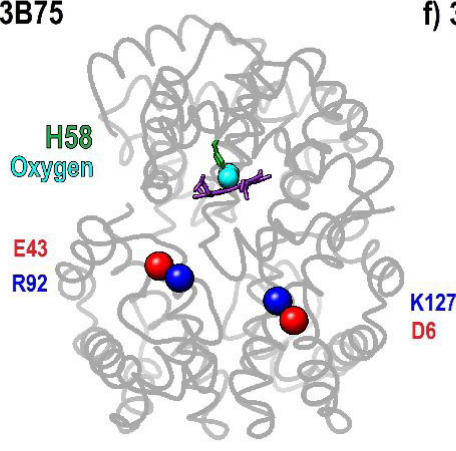

f) $3 \mathrm{~B} 75$

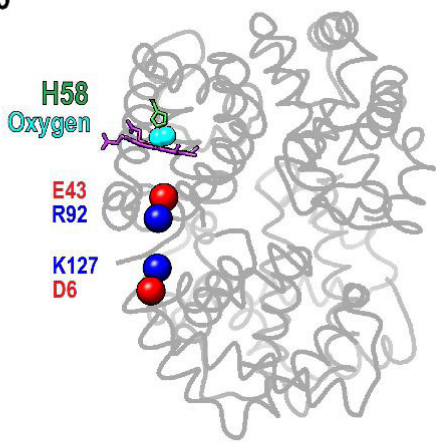

g) 3DNN

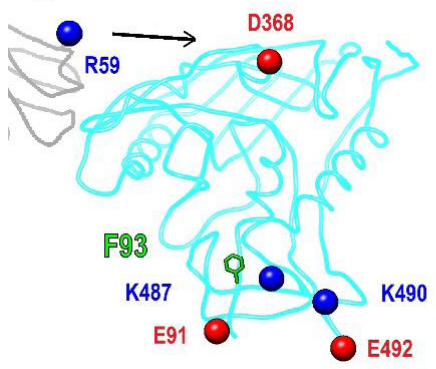

h) 2QAD

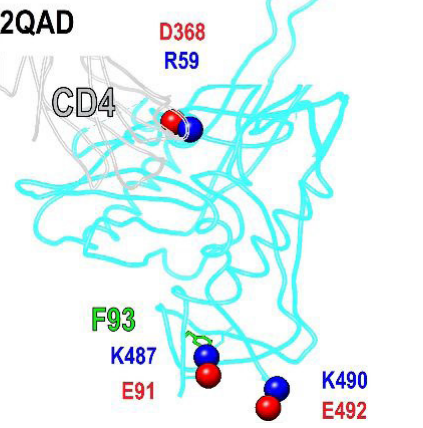

i) 2QAD

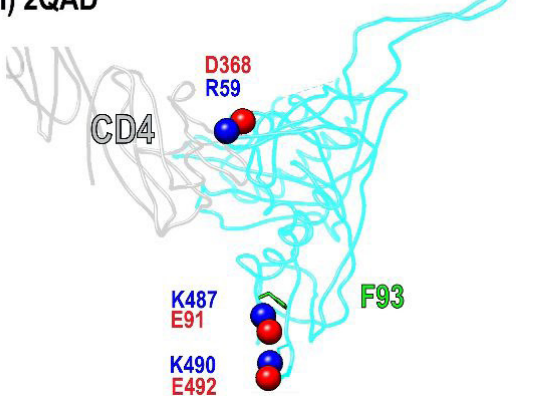

Figure 3. Some examples of PECC-i present in: calcium-ADP pump (a,b,c); haemoglobin-oxygen (d,e,f); and gp120-CD4 (g,h,i) receptorligand protein systems. Image records taken from Jmol.

any amount of energy allowing an infinity of intermediate states, increasing the disorder of the molecular system and making molecular transduction extremely inefficient, or even impossible. These pairings are depicted in Figures 1-3, showing the involvement of the $\mathrm{D}, \mathrm{E}, \mathrm{R}$ and $\mathrm{K}$ residues, principally. (In the case of haemoglobin (Figure $3 \mathrm{~d}-\mathrm{f}$ ), the $\mathrm{H}$ residue is involved, coupling with the oxygen.)

This is the basis of the model we hereby propose with the aim of explaining the transduction of signals over relatively long distances within a receptor. We call this model Transduction in Molecules by PECC-i (TM-PECC-i).

\subsection{TCR activation mechanism according to the TM- PECC-i model}

TCR activation is vital for induction of the immune response against pathogenic microorganisms and consequently for the functioning of vaccines (Wang 
and Reinherz, 2013). The activation is triggered by the recognition of certain foreign antigens. These antigens must send a signal to the interior domain of the TCR (from the $\alpha \beta$ domains to the $\zeta \zeta$ domain). This mechanism has lacked a clear explanation, since transmission of the signal by molecular mechanical vibration is not capable of accounting for the efficacy of an immunological response. First, such a mechanical mechanism requires too much energy to be able to induce a signal that travels all the way from the point of coupling with the ligand to the intracellular domain. Secondly, a mechanical signal induces multiple aimless movements, raising the entropy of the system and dispersing the energy (Bischof and Del Giudice, 2013). Finally, the activation mechanism would not be sufficiently specific and lack the selectivity necessary to differentiate between one ligand and another.

Analyzing the human protein sequences of TCR reported in the NCBI database, we identified the fully conserved residues seen in Table 1 . All these residues showed planar spatial patterns, as seen in Figure 1 where the electrical peptide-recognition residues D28 and E94 of the TCR are observed to act as couplings for the positive charges of the coupled peptide. This type of plane was also found in HLA-II molecules, as we have previously indicated (Cortés et al., 2013, Cortés et al., 2017b).

In Figure 2, it was seen that all the fully conserved residues of the free TCR are found in a dissociated state, while in the molecule coupled with the peptide, these same residues are paired. This shows that the coupling of opposite charges between the TCR and the peptide induces the additional formation of new ionic pairings within the planar system.

According to the TM-PECC-i model, the formation of new ionic pairings in the interior would be induced by the signal generated by the TCR-peptide coupling and simultaneously replicated by all of the internal residues of the PECC-i. This, as we have outlined above, would occur by means of the quantum coherence mechanism.

Quantum coherence predicts that in a system that is thermodynamically open, fully ordered and internally interconnected by an electromagnetic field, the component elements of the system will behave in a coherent and synchronized way (Collini et al., 2010; Bischof and Del Giudice, 2013; Engel et al., 2007). The planar geometry of the PECC-i ensures that these are fully ordered systems (of low entropy). The very occurrence of ionic pairings in the PECC-i is responsible for internalizing the signal (Fig. 3). This system meets the conditions required by quantum coherence. As observed, a local change in the receptor is transduced by the coherent and synchronized behavior of the whole system. On the contrary, a hypothetical mechanical transmission, induced by receptor-ligand molecular contact, would rapidly lose mechanical vibration through the dissipative effects of the medium (Bischof and Del Giudice, 2013; Lambert et al., 2013).

We thus infer that the signal reaches beyond the $\alpha \beta$ domain to the $\mathrm{D} 30$ and $\mathrm{R} 22$ residues in the $\zeta \zeta$ transmembrane dimer domain, permitting the signal to appear in the cell interior in a timespan concomitant with the immediate reaction time required by the human immunological system (Figure 1).

\subsection{Signal transduction in other receptor-ligand systems}

To verify the universality of the phenomenon of simultaneous ionic pairings across the whole plane (as witnessed in the TCR-peptide system), we proceeded to analyze these other receptor-ligand systems: calcium pump-ADP, haemoglobin-oxygen and gp120-CD4.

Figure 3 presented the different receptor-ligand systems in their free and coupled state. Figure $3 b, d, h$ highlighted the fact that coupling with the respective ligand induces the formation of identical ionic pairings across the planar system, while the planar geometry of each of the three systems could be most easily seen in Figure 3c,f,i. Our hypothesis is that when a ligand couples with its respective receptor all the residues of the PECC- $i$ pair with an opposite charge, cancelling out the charges and releasing the electromagnetic field that connects them. This released field may be the transduction signal carried by the ligand.

The effects of amino acid mutations have been the subject of wide-ranging research (Guzzi et al., 2020). In the action of calcium pumps, a number of studies have shown that on mutating the $\mathrm{R} 560$ residue (whose position is considered to be strategic), the functionality of the pumps is altered. Further, such mutation may also interfere with the protective effect of the nucleotides. This may alter the stabilization of the coupling with ATP; this is one of the causes of congenital dystonia in animal muscle (Ma et al., 2003; Brini and Carafoli, 2009; Dorotea et al., 2015). Elsewhere, it was discovered that mutation of the $\mathrm{R} 671$ residue (that modulates the activity of early tryptic fragmentation) alters the conformation of the calcium pumps of SERCA 3 (Corvazier et al., 2009). In the haemoglobin molecule, genetic variants have been reported that cause cyanosis (a diminution in oxygen affinity) when the $\mathrm{H} 58$ residue is mutated (a variant known as Hb M Boston) (Nishikura et al., 1975; Viana and Belisário, 2014). Similarly, a further variant known as Hb Hornchurch shows a mutation in the E43 residue, which may be related to diminution in the plate count (thrombocytopenia) (Shi and Wang, 2017). Mutations in the D368 residue of the gp120 protein, meanwhile, have proved to be relevant for effective coupling of the gp120CD4 system, demonstrating a key function in this protein (Olshevsky et al., 1990).

All of these charged amino acids form part of the PECC-i systems in the molecules studied. Wherever one of these residues was altered, the coupling was unable to be replicated and the signal was thus interrupted, affecting the TM-PECC-i mechanism. These residues are therefore seen to have a critical role in the functionality of each of the proteins. This is due to the fact that it is not a local amino acid that is altered, but an organized internal system in the protein, which is relevant to the functionality of the entire protein.

In fact, returning to the two examples cited of quantum coherence present in biological phenomena - plant photosynthesis and bird navigation - the PECC-i model can shed light on both. In photosynthesis, the reason behind the near $100 \%$ success rate of photon transfer is not well understood, but researchers have suggested 
that the waves of photon-electron interactions may extend to more than one molecule (Ball, 2011). Our study confirms that an extended electromagnetic field, intercommunicating amino acids, is indeed present in the form of a PECC field. Meanwhile, the electron pairs created by photons of light striking the retina in birds are known to exhibit quantum coherence, but the cause of this phenomena is not well enough understood (Ball, 2011; Lambert et al., 2013). When the electrons are not entangled, they act independently. But when the system entangles the electrons they locate themselves precisely, like two poles of a magnet, in opposing positions, thus acting as a compass. Again, the PECC-i model offers a satisfactory explanation for this quantum coherence.

Now, if traditional mechanical criteria such as induced adjustment are used to explain the processes involved, the enormous ensemble of signals required in an organism to keep other parts of the organism informed about what is going would demand an immense consumption of energy. We know, however, that the energy demands of an organism in contrast are quite moderate (Bischof and Del Giudice, 2013). The coherence exhibited by the PECC-i may explain the efficiency in energy of a biochemical system, bearing in mind that the coherent behavior of the PECC-i can only be induced by the coupling of a single, unique ligand type and not by any other. This indicates that each type of ligand must possess an energy that corresponds exclusively with the energy to activate the corresponding receptor. From this it can be deduced that the energy for the activation of a receptor is possibly quantized. This idea will be presented in fuller detail in a forthcoming article.

The mechanism we now propose for explaining the molecular transduction of signals, TM-PECC-I, operates along the plane in a manner that is thus consistent with quantum coherence (Lambert et al., 2013). The coherence may be enabled by electromagnetic coupling between all amino acid constituents of PECC-i, producing a synchronized and collective behaviour among these component residues. The aromatic residues located at the point of origin of all PECC may have a pulsing behavior, absorbing energy from the environment and then re-emitting this same energy in the form of a planar field. This is analogous to the mode of operation of photosynthetic systems. The TM-PECC-i model further enables a number of diverse systems of molecular coupling to be explained, which would be useful for the design of bioactive molecules and would also allow us to propose an explanation for the recognition between a receptor and a ligand, in future work.

Finally, the fact that the aminoacids comprising PECC fields are fully conserved, or constant, precludes any use of statistical analysis: no variable data are used, rather invariable data, which allows us to speak of exactitudes, rather than average results.

\section{Conclusions}

We propose a mechanism to explain molecular transduction in receptor-ligand systems, based on an earlier discovery of Planar Electromagnetic fields of Cortés-Coral (PECC) present in crystal structures of proteins reported by NCBI. Comprising fully conserved residues of the same chemical species organized across the entire protein, these planes always contain an aromatic residue.

This is able to generate electromagnetic signals that provide the system with energy and furthermore interconnect all of the residues of the PECC, as explained above.

Special PECC formed by charged residues are known as PECC-ionic (PECC-i). These exhibit a coherent and synchronized behaviour in their electrical residues consistent with quantum coherence phenomena. Thus, when an electric charge at a single point in the PECC-i couples with an opposite charge in the ligand, this action is immediately replicated across the whole planar system. The mechanism, given the name Transduction in Molecules by PECC-ionic (TM-PECC-i), was found to be present in all of the systems studied (calcium pump-ADP, haemoglobin-oxygen, gp120-CD4) - suggesting that it may be universal in character - as well as in TCR-peptide.

Since the TM-PECC-i model thus offers an explanation of the key principles involved in activation of the TCR molecule, application of the mechanism to the design of vaccine-peptides ought to be of value, ensuring that these activate an effective immune response.

The functionality of TM-PECC-i is demonstrated by the fact that, as reported by other studies, the mutation of a component amino acid of the PECC-i invariably alters the activity of the proteins studied or renders them inactive.

Finally, TM-PECC-i is furthermore capable of explaining 1) the high efficacy of signal transduction in all receptorligand systems; and 2) the high specificity of recognition, in which each receptor is activated exclusively by a unique ligand type, suggesting that the energy liberated in the receptor-ligand coupling is exclusively specific and thus possibly quantized.

\section{Acknowledgements}

We are grateful to the Synthetic Vaccine, Antisera and New Drug Research Institute (IVSI) and to Universidad del Cauca (501100005682) for providing the infrastructure together with the funding for developing the model. Special acknowledgment to Luis Miguel Muñoz for the translation of the abstract to the Portuguese language.

\section{References}

ADAMS, J.J., NARAYANAN, S., LIU, B., BIRNBAUM, M.E., KRUSE, A.C., BOWERMAN, N.A., CHEN, W., LEVIN, A.M., CONNOLLY, J.M., ZHU, C., KRANZ, D.M. and GARCIA, K.C., 2011. T cell receptor signaling is limited by docking geometry to peptide-major histocompatibility complex. Immunity, vol. 35, no. 5, pp. 681-693. http://dx.doi.org/10.1016/j.immuni.2011.09.013. PMid:22101157.

ANSELMO, C., PEREIRA, P., CATANHO, M. and MEDEIROS, M., 2009. Effects of the Electromagnetic field, $60 \mathrm{~Hz}, 3 \mu \mathrm{T}$, on the hormonal and metabolic regulation of undernourished pregnant rats. Brazilian Journal of Biology = Revista Brasileira de Biologia, vol. 69, no. 2, pp. 397-404. http://dx.doi.org/10.1590/ S1519-69842009000200024. PMid:19675945. 
ANSELMO, C., SILVA, T., HOLANDA, T., PRADO, L., CABRAL-FILHO, J., CATANHO, M. and MEDEIROS, M., 2008. Influence of a $60 \mathrm{~Hz}$, $3 \mu \mathrm{T}$, electromagnetic field on the somatic maturation of wistar rat offspring fed a regional basic diet during pregnancy. Brazilian Journal of Biology = Revista Brasileira de Biologia, vol. 68, no. 3, pp. 641-648. http://dx.doi.org/10.1590/S151969842008000300023. PMid:18833487.

BALL, P., 2011. Physics of life: the dawn of quantum biology. Nature, vol. 474, no. 7351, pp. 272-274. http://dx.doi. org/10.1038/474272a. PMid:21677723.

BISCHOF, M. and DEL GIUDICE, E., 2013. Communication and the emergence of collective behavior in living organisms: a quantum approach. Molecular Biology International, vol. 2013, pp. 19. http://dx.doi.org/10.1155/2013/987549. PMid:24288611.

BISWAL, B. and VIJAYAN, M., 2002. Structures of human oxy-and deoxyhaemoglobin at different levels of humidity: variability in the T state. Acta Crystallographica. Section D, Biological Crystallography, vol. 58, no. Pt 7, pp. 1155-1161. http://dx.doi. org/10.1107/S0907444902007138. PMid:12077435.

BORBULEVYCH, O.Y., SANTHANAGOPOLAN, S.M., HOSSAIN, M. and BAKER, B.M., 2011. TCRs used in cancer gene therapy cross-react with MART-1/Melan-A tumor antigens via distinct mechanisms. Journal of Immunology (Baltimore, Md.: 1950), vol. 187, no. 5, pp. 2453-2463. http://dx.doi.org/10.4049/jimmunol.1101268. PMid:21795600.

BRIDGEMAN, J.S., SEWELL, A.K., MILES, J.J., PRICE, D.A. and COLE, D.K., 2012. Structural and biophysical determinants of $\alpha \beta$ T-cell antigen recognition. Immunology, vol. 135, no. 1, pp. 9-18. http:// dx.doi.org/10.1111/j.1365-2567.2011.03515.x. PMid:22044041.

BRINI, M. and CARAFOLI, E., 2009. Calcium pumps in health and disease. Physiological Reviews, vol. 89, no. 4, pp. 1341-1378. http://dx.doi.org/10.1152/physrev.00032.2008. PMid:19789383.

CALL, M.E., SCHNELL, J.R., XU, C., LUTZ, R.A., CHOU, J.J. and WUCHERPFENNIG, K.W., 2006. The structure of the $\zeta \zeta$ transmembrane dimer reveals features essential for its assembly with the T cell receptor. Cell, vol. 127, no. 2, pp. 355-368. http:// dx.doi.org/10.1016/j.cell.2006.08.044. PMid:17055436.

CN3D, 2011 [viewed in August 2018]. Macromolecular structure display, version 4.3. Available from: https://www.ncbi.nlm. nih.gov/Structure/CN3D/cn3d.shtml.

COLLINI, E., WONG, C.Y., WILK, K.E., CURMI, P.M., BRUMER, P. and SCHOLES, G.D., 2010. Coherently wired light-harvesting in photosynthetic marine algae at ambient temperature. Nature, vol. 463, no. 7281, pp. 644-647. http://dx.doi.org/10.1038/ nature08811. PMid:20130647.

CORMIER, E.G., PERSUH, M., THOMPSON, D.A., LIN, S.W., SAKMAR, T.P., OLSON, W.C. and DRAGIC, T., 2000. Specific interaction of CCR5 amino-terminal domain peptides containing sulfotyrosines with HIV-1 envelope glycoprotein gp120. Proceedings of the National Academy of Sciences of the United States of America, vol. 97, no. 11, pp. 5762-5767. http://dx.doi.org/10.1073/ pnas.97.11.5762. PMid:10823934.

CORTES, A. and CORAL, J., 2015. Campos electromagneticos planares permiten explicar el acople entre peptidos y moleculas de HLA-II. Acta Bioquímica Clínica Latinoamericana, vol. 49, pp. 221-228.

CORTÉS, A., CORAL, J. \& BENÍTEZ BENÍTEZ, R., 2013. Hallazgo de patrones para péptidos-vacuna con capacidad de acople universal en moléculas de HLA-II. Acta Bioquímica Clínica Latinoamericana, vol. 47, no. 3, pp. 475-634.

CORTÉS, A., CORAL, J., MCLACHLAN, C. and BENÍTEZ, R. 2017a. The use of planar electromagnetic fields in effective vaccine design. In F. AFRIN. Vaccines. London: InTech. http://dx.doi. org/10.5772/intechopen.69546.
CORTÉS, A., CORAL, J., MCLACHLAN, C., BENÍTEZ, R. and PINILLA, L., 2017b. Planar molecular arrangements aid the design of MHC class II binding peptides. Molecular Biology, vol. 51, no. 3, pp. 465-473. http://dx.doi.org/10.1134/S002689331702008X. PMid:28707669.

CORVAZIER, E., BREDOUX, R., KOVÁCS, T. and ENOUF, J., 2009. Expression of sarco/endoplasmic reticulum Ca 2+ ATPase (SERCA) 3 proteins in two major conformational states in native human cell membranes. Biochimica et Biophysica Acta, vol. 1788, no. 3, pp. 587-599. http://dx.doi.org/10.1016/j.bbamem.2008.12.004. PMid:19135027.

ĆOSIĆ, I., PIROGOVA, E., VOJISAVLJEVIĆ, V. and FANG, Q., 2006. Electromagnetic properties of biomolecules. FME Transactions, vol. 34, pp. 71-80.

DOROTEA, T., GRÜNBERG, W., MURGIANO, L., PLATTET, P., DRÖGEMÜLLER, C., MASCARELLO, F. and SACCHETTO, R., 2015. Fast-twitch skeletal muscle fiber adaptation to SERCA1 deficiency in a Dutch Improved Red and White calf pseudomyotonia case. Neuromuscular Disorders, vol. 25, no. 11, pp. 888-897. http:// dx.doi.org/10.1016/j.nmd.2015.08.010. PMid:26482047.

ENGEL, G.S., CALHOUN, T.R., READ, E.L., AHN, T.-K., MANČAL, T., CHENG, Y.-C., BLANKENSHIP, R.E. and FLEMING, G.R., 2007. Evidence for wavelike energy transfer through quantum coherence in photosynthetic systems. Nature, vol. 446, no. 7137, pp. 782-786. http://dx.doi.org/10.1038/nature05678. PMid:17429397.

European Molecular Biology Laboratory-European Bioinformatics Institute - EMBL-EBI, 2018 [viewed in July 2018]. Available from: http://www.ebi.ac.uk/Tools/msa/clustalo/.

FUKUI, Y., OONO, T., CABANIOLS, J.-P., NAKAO, K., HIROKAWA, K., INAYOSHI, A., SANUI, T., KANELLOPOULOS, J., IWATA, E., NODA, M., KATSUKI, M., KOURILSKY, P. and SASAZUKI, T., 2000. Diversity of $\mathrm{T}$ cell repertoire shaped by a single peptide ligand is critically affected by its amino acid residue at a $\mathrm{T}$ cell receptor contact. Proceedings of the National Academy of Sciences of the United States of America, vol.97, no. 25, pp. 13760-13765. http://dx.doi. org/10.1073/pnas.250470797. PMid:11087837.

GUZZI, A.F., OLIVEIRA, F.S.L., AMARO, M.M.S., TAVARES-FILHO, P.F. and GABRIEL, J.E., 2020. In silico prediction of the functional and structural consequences of the non-synonymous single nucleotide polymorphism A122V in bovine CXC chemokine receptor type 1. Brazilian Journal of Biology = Revista Brasileira de Biologia, vol. 80, no. 1, pp. 39-46. http://dx.doi.org/10.1590/15196984.188655. PMid:31017232.

HALL, J.E., 2015. Guyton and Hall textbook of medical physiology. Philadelphia, PA: Elsevier Health Sciences.

HENNECKE, J., CARFI, A. and WILEY, D.C., 2000. Structure of a covalently stabilized complex of a human $\alpha \beta$ T-cell receptor, influenza HA peptide and MHC class II molecule, HLA-DR1. The EMBO Journal, vol. 19, no. 21, pp. 5611-5624. http://dx.doi. org/10.1093/emboj/19.21.5611. PMid:11060013.

HOLLAND, C.J., RIZKALLAH, P.J., VOLLERS, S., CALVO-CALLE, J.M., MADURA, F., FULLER, A., SEWELL, A.K., STERN, L.J., GODKIN, A. and COLE, D.K., 2012. Minimal conformational plasticity enables TCR cross-reactivity to different MHC class II heterodimers. Scientific Reports, vol. 2, no. 1, pp. 629. http://dx.doi.org/10.1038/ srep00629. PMid:22953050.

HUANG, C.-C., LAM, S.N., ACHARYA, P., TANG, M., XIANG, S.-H., HUSSAN, S.S.-U., STANFIELD, R.L., ROBINSON, J., SODROSKI, J., WILSON, I.A., WYATT, R., BEWLEY, C.A. and KWONG, P.D., 2007. Structures of the CCR5 $\mathrm{N}$ terminus and of a tyrosine-sulfated antibody with HIV-1 gp120 and CD4. Science, vol. 317, no. 5846, pp. 1930-1934. http://dx.doi.org/10.1126/science.1145373. PMid:17901336. 
INGRAM, V.M., 2004. Sickle-cell anemia hemoglobin: the molecular biology of the first "molecular disease"-the crucial importance of serendipity. Genetics, vol. 167, no. 1, pp. 1-7. http://dx.doi. org/10.1534/genetics.167.1.1. PMid:15166132.

JMOL, 2011 [viewed in August 2018]. Open-source Java viewer for chemical structures in three dimensions, version 12.0. Available from: http://www.jmol.org/.

KIM, S.T., SHIN, Y., BRAZIN, K., MALLIS, R.J., SUN, Z.-Y.J., WAGNER, G., LANG, M.J. and REINHERZ, E.L., 2012. TCR mechanobiology: torques and tunable structures linked to early $\mathrm{T}$ cell signaling. Frontiers in Immunology, vol. 3, pp. 3. http://dx.doi.org/10.3389/ fimmu.2012.00076. PMid:22566957.

KIM, S.T., TAKEUCHI, K., SUN, Z.-Y.J., TOUMA, M., CASTRO, C.E., FAHMY, A., LANG, M.J., WAGNER, G. and REINHERZ, E.L., 2009. The $\alpha \beta$ T cell receptor is an anisotropic mechanosensor. The Journal of Biological Chemistry, vol. 284, no. 45, pp. 31028-31037. http://dx.doi.org/10.1074/jbc.M109.052712. PMid:19755427.

KJER-NIELSEN, L., CLEMENTS, C.S., BROOKS, A.G., PURCELL, A.W., MCCLUSKEY, J. and ROSSJOHN, J., 2002. The $1.5 \AA$ crystal structure of a highly selected antiviral $\mathrm{T}$ cell receptor provides evidence for a structural basis of immunodominance. Structure, vol. 10, no. 11, pp. 1521-1532. http://dx.doi.org/10.1016/S09692126(02)00878-X. PMid:12429093.

LAMBERT, N., CHEN, Y.-N., CHENG, Y.-C., LI, C.-M., CHEN, G.-Y. and NORI, F., 2013. Quantum biology. Nature Physics, vol. 9, no. 1, pp. 10-18. http://dx.doi.org/10.1038/nphys2474.

LIU, J., BARTESAGHI, A., BORGNIA, M.J., SAPIRO, G. and SUBRAMANIAM, S., 2008. Molecular architecture of native HIV-1 gp120 trimers. Nature, vol. 455, no. 7209, pp. 109-113. http://dx.doi.org/10.1038/nature07159. PMid:18668044.

LYNCH, J.N., DONERMEYER, D.L., WEBER, K.S., KRANZ, D.M. and ALLEN, P.M., 2013. Subtle changes in TCR $\alpha$ CDR1 profoundly increase the sensitivity of CD4 T cells. Molecular Immunology, vol. 53, no. 3, pp. 283-294. http://dx.doi.org/10.1016/j. molimm.2012.08.020. PMid:22982754.

MA, H., INESI, G. and TOYOSHIMA, C., 2003. Substrate-induced conformational fit and headpiece closure in the Ca2+ATPase(SERCA). The Journal of Biological Chemistry, vol.278, no. 31, pp. 28938-28943. http://dx.doi.org/10.1074/jbc.M304120200. PMid:12750373.

MONTAGNIER, L., AISSA, J., DEL GIUDICE, E., LAVALLEE, C., TEDESCHI, A. and VITIELLO, G. 2011. DNA waves and water. Journal of Physics: Conference Series, vol. 306, no. 1, pp. 012007.

NISHIKURA, K., SUGITA, Y., NAGAI, M., YONEYAMA, Y. and JAGENBURG, R., 1975. High cooperativity of haemoglobin M Boston in the completely reduced state. Nature, vol. 254, no. 5502, pp. 727-728. http://dx.doi.org/10.1038/254727a0. PMid:235745.
OLSHEVSKY, U., HELSETH, E., FURMAN, C., LI, J., HASELTINE, W. and SODROSKI, J., 1990. Identification of individual human immunodeficiency virus type $1 \mathrm{gp} 120$ amino acids important for CD4 receptor binding. Journal of Virology, vol. 64, no. 12, pp. 5701-5707. http://dx.doi.org/10.1128/JVI.64.12.5701-5707.1990. PMid:2243375.

POKUTNYI, S.I. and NAUMENKO, O.V. 2014. Size quantization Stark effect in quantum dots. Optics, vol. 3, no. 6-1, pp. 57-60.

SHI, H. and WANG, Z., 2017. Hemoglobin Hornchurch [ $\beta 43$ (CD2) Glu> Lys; HBB: c. 130G> A] in a Chinese boy complicated with thrombocytopenia: A case report and literature review. Medicine, vol. 96, no. 47, pp. 96. http://dx.doi.org/10.1097/ MD.0000000000008862.

TORSONI, M.A., STOPPA, G.R., TURRA, A. and OGO, S.H., 2002. Functional behavior of tortoise hemoglobin Geochelone denticulata. Brazilian Journal of Biology = Revista Brasileira de Biologia, vol. 62, no. 4A, pp. 725-733. http://dx.doi.org/10.1590/ S1519-69842002000400020. PMid:12659022.

TOYOSHIMA, C., NOMURA, H. and TSUDA, T., 2004. Lumenal gating mechanism revealed in calcium pump crystal structures with phosphate analogues. Nature, vol. 432, no. 7015, pp. 361-368. http://dx.doi.org/10.1038/nature02981. PMid:15448704.

TOYOSHIMA, C., NORIMATSU, Y., IWASAWA, S., TSUDA, T. and OGAWA, H., 2007. How processing of aspartylphosphate is coupled to lumenal gating of the ion pathway in the calcium pump. Proceedings of the National Academy of Sciences of the United States of America, vol. 104, no. 50, pp. 19831-19836. http://dx.doi.org/10.1073/pnas.0709978104. PMid:18077416.

VIANA, M.B. and BELISÁRIO, A.R., 2014. De novo alpha 2 hemoglobin gene (HBA2) mutation in a child with hemoglobin M Iwate and symptomatic methemoglobinemia since birth. Revista Brasileira de Hematologia e Hemoterapia, vol. 36, no. 3, pp. 230-234. http://dx.doi.org/10.1016/j.bjhh.2014.03.020. PMid:25031065.

WANG, C.D., GALLAHER, T.K. and SHIH, J.C., 1993. Site-directed mutagenesis of the serotonin 5-hydroxytrypamine2 receptor: identification of amino acids necessary for ligand binding and receptor activation. Molecular Pharmacology, vol. 43, no. 6, pp. 931-940. PMid:8316224.

WANG, J.-H. and REINHERZ, E.L., 2013. Revisiting the putative TCR $\mathrm{C} \alpha$ dimerization model through structural analysis. Frontiers in Immunology, vol. 4, pp. 4. http://dx.doi.org/10.3389/ fimmu.2013.00016.

WU, H., 2013. Higher-order assemblies in a new paradigm of signal transduction. Cell, vol. 153, no. 2, pp. 287-292. http://dx.doi. org/10.1016/j.cell.2013.03.013. PMid:23582320. 